\title{
Studies on the Performance of a GaInP/GaAs Tandem Solar Cell at Elevated Temperatures
}

\author{
Debashish Pal ${ }^{a}$, Rabi Adhikary ${ }^{\text {b }}$ \\ ${ }^{a}$ M.Tech, Institute of Engineering and Management, Salt Lake, Kolkata 700091, India \\ ${ }^{b}$ Pailan Technical Campus, South 24 Parganas, Kolkata 700104, India
}

Received: 23 June 2018; Accepted: 07 October 2018; Published: 08 January 2019

\begin{abstract}
In this paper theoretical studies have been performed on a multijunction GaInP/GaAs based tandem solar cell. The top GaInP cell and the bottom GaAs cell were investigated separately. At an operating temperature of $300 \mathrm{~K}$, the current matching condition is fulfilled when the top cell and bottom cell base doping concentration and thickness are set to $5 \times 10^{15} / \mathrm{cm}^{3}, 1 \mu \mathrm{m}$, and $2 \times 10^{17} / \mathrm{cm}^{3}, 0.127 \mu \mathrm{m}$ respectively. For the purpose of the investigation, a wide operating temperature range was chosen from $25^{\circ} \mathrm{C}$ to $100^{\circ} \mathrm{C}$. The optimized tandem solar cell structure having a thickness of 1.847 microns is found to have $\mathrm{V}_{\mathrm{OC}}=2.2996 \mathrm{~V}, \mathrm{I}_{\mathrm{SC}}=0.0136 \mathrm{Amp} / \mathrm{cm}^{2}$, $\mathrm{FF}=87.61 \%$ and $\eta=27.4 \%$ under $\mathrm{AM} 1.5 \mathrm{G}$ one sun illumination. Studies have also revealed that when the cells are analyzed separately the current mismatch is less significant at low temperatures with the difference becoming notable at higher temperatures. Simulations of the solar cell were performed using PC1D.
\end{abstract}

Index Terms: AM 1.5, Fill Factor, GaAs/GaInP, Open Circuit Voltage, Reverse Saturation Current, Short Circuit Current.

(C) 2019 Published by MECS Publisher. Selection and/or peer review under responsibility of the Research Association of Modern Education and Computer Science.

\section{Introduction}

The efficiency limitation of a single junction conventional p-n solar cell can be overcome by growing epitaxial layers to form multijunction tandem solar cells $[1,2,3,4]$. These cells exhibit increased conversion efficiencies at the expense of difficulties encountered in optimization and higher cost of production. Thus numerical modeling helps optimize the solar cell providing insight into the parameter dependent operation thereby overcoming the shortfalls associated with the design and the fabrication process. Monolithic tandem

\footnotetext{
* Corresponding author.
}

E-mail address: 
solar cells are lattice matched layers of different semiconductors, each layer responding to different wavelengths of the solar spectrum based on their energy bandgap [5]. The layers are so arranged such that the material with the highest bandgap is at the top with the successive layers having decreasing bandgaps. This arrangement ensures that the cell is able to respond to most of the photons having a range of energy values incident on its surface. A very important criterion of current matching must be satisfied by such tandem cells and because such tandem cells are composed of a series connection of multiple cells the total current is limited by the minimum current among the cells.

The choice of the materials for epitaxial growth plays a very significant role in determining the performance of a multijunction solar cell. Lattice-mismatched materials are detrimental to the performance of a solar cell as they result in dislocation of the atoms promoting non-radiative recombination reducing the carrier lifetimes $[6,7]$.

The theoretical temperature dependences of solar cell output parameters have been investigated in a number of different articles $[8,9,10,11]$. An increase in the temperature of a semiconductor affects its terminal characteristics namely the open circuit voltage $\left(\mathrm{V}_{\mathrm{OC}}\right)$, short circuit current $\left(\mathrm{J}_{\mathrm{SC}}\right)$, fill factor $(\mathrm{FF})$ and the efficiency (n) [12].

The electrical parameters that determine the performance of the solar cell are as follows. The External Quantum Efficiency (EQE) is defined as the ratio between the number of collected charges and the number of incident photons for each wavelength. The short-circuit current density Jsc depends on the useful absorption fraction $\operatorname{EQE}(\lambda)$ integrated over the whole spectral range and weighted by the incident spectral power density per unit area $P(\lambda)$ :

$$
J_{S C}=\frac{q}{h c} \int E Q E(\lambda) P(\lambda) \lambda d \lambda
$$

where $\mathrm{q}$ is the electron charge, $\mathrm{h}$ Planck's constant, $\mathrm{c}$ the speed of light.

The open-circuit voltage Voc is the voltage measured for a perfect balance between photo-generated current and dark current in a cell:

$$
V_{O C}=\frac{n K T}{q} \ln \left(\frac{J s c}{J 0 n}+1\right)
$$

where $\mathrm{k}$ is the Boltzmann constant, $\mathrm{T}$ the temperature, $\mathrm{q}$ the elementary charge, $\mathrm{\eta}$, and $\mathrm{J}_{0}$ are respectively the ideality and the reverse saturation current (dark current) of the diode. The Voc is thus intrinsically defined and limited by the dark current in a cell which is given by:

$$
J_{0}=q\left(\frac{D_{n}}{L_{n} N_{a}}+\frac{D_{p}}{L_{p} N_{d}}\right) n_{i}^{2}
$$

where $n_{i}$ is the intrinsic carrier concentration, $N_{a}$ and $N_{d}$ are the acceptor and donor atom concentrations, $D_{n}$ and $\mathrm{D}_{\mathrm{p}}$ the diffusion constants, $\mathrm{L}_{\mathrm{n}}$ and $\mathrm{L}_{\mathrm{p}}$ the diffusion lengths of the electrons and holes.

The fill factor FF relates the maximum power $\mathrm{P}_{\max }$ obtainable from the cell to the product of the open-circuit voltage $\mathrm{V}_{\mathrm{oc}}$ and short-circuit current $\mathrm{I}_{\mathrm{sc}}$ of the cell.

$$
F F=\frac{P_{\max }}{I_{s c} V_{o c}}
$$


The efficiency of the solar cell is the ratio between its electrical power output and the incident power of the light entering the device.

$$
\eta=\frac{I_{s c} V_{o c} F F}{P_{i n}}
$$

\section{Design and Optimization}

This study investigates a multijunction solar cell structure having four layers in the top and the bottom subcell. The top subcell is a $\mathrm{Ga}_{0.5} \mathrm{In}_{0.5} \mathrm{P}\left(\mathrm{E}_{\mathrm{g}}=1.9 \mathrm{eV}\right)$ based solar cell having three junctions with an $\mathrm{Al}_{0.8} \mathrm{Ga}_{0.2} \mathrm{As}$ window layer. The bottom subcell is made of $\mathrm{GaAs}\left(\mathrm{E}_{\mathrm{g}}=1.424 \mathrm{eV}\right)$ based material with a $\mathrm{Ga}_{0.5} \mathrm{In}_{0.5} \mathrm{P}$ window and a BSF layer. The bottom subcell is mounted on a GaAs substrate and the two subcells are separated by a tunnel junction. The choice of $\mathrm{Ga}_{0.5} \mathrm{In}_{0.5} \mathrm{P}$ and $\mathrm{GaAs}$ as the materials for the proposed device allows us to optimize the absorption of the solar energy.

For the purpose of optimization of the solar cell, the top-down approach is used. The thickness and the doping concentration of the top cell are first varied to determine the values for which it has the highest efficiency. In order for the current matching condition to be fulfilled, it should be ensured all the junctions must generate the same number of charge carriers. Therefore the values of the doping concentrations and the thickness for different layers in the bottom subcell are then varied to satisfy this criterion. The modeling and simulations were performed using PC1D simulation software. The operating temperature was chosen to be $25^{\circ} \mathrm{C}$ with a device area of $1 \mathrm{~cm}^{2}$. The optimization of the subcells was performed under AM1.5G one sun illumination condition having an intensity of $0.1 \mathrm{~W} / \mathrm{cm}^{2}$. The schematic diagram of the proposed tandem solar cell is shown in the Fig.1.

\begin{tabular}{|c|c|c|c|}
\hline AlGaAs window & $\mathrm{Nd}=1 \mathrm{E} 18$ & 0.01 um & \multirow{4}{*}{ Top Cell } \\
\hline GalnP emitter & $\mathrm{Nd}=3 \mathrm{E} 18$ & 0.01 um & \\
\hline GalnP base & variable & variable & \\
\hline GalnP BSF & $\mathrm{Na}=2 \mathrm{E} 18$ & $0.65 \mathrm{um}$ & \\
\hline \multicolumn{3}{|c|}{$\mathrm{p}+/ \mathrm{n}+$ tunnel junction } & \multirow{5}{*}{ Bottom Cell } \\
\hline GalnP window & $\mathrm{Nd}=2 \mathrm{E} 18$ & 0.01 um & \\
\hline GaAs emitter & $\mathrm{Nd}=2 \mathrm{E} 18$ & 0.01 um & \\
\hline GaAs base & variable & variable & \\
\hline GalnP BSF & $\mathrm{Na}=2 \mathrm{E} 18$ & 0.03 um & \\
\hline \multicolumn{3}{|c|}{$p+$ GaAs substrate } & \\
\hline
\end{tabular}

Fig.1. Schematic of the Multijunction Tandem Cell

\section{Results and Discussion}

The device is optimized keeping the doping concentration and thickness of the base layers in both the subcells as the variable parameters. It is found that the exact current match is obtained for the top and the bottom subcells for a base thickness and doping concentrations of $1 \mu \mathrm{m}, 0.127 \mu \mathrm{m}$ and $5 \times 10^{15}, 2 \times 10^{17} / \mathrm{cm}^{3}$ respectively. The Fig.2 (a) and (b) show the current-voltage relationship and the power-voltage relationship of the top and the bottom cells. The values of the terminal parameters obtained from the results of the simulation are listed in Table 1. 

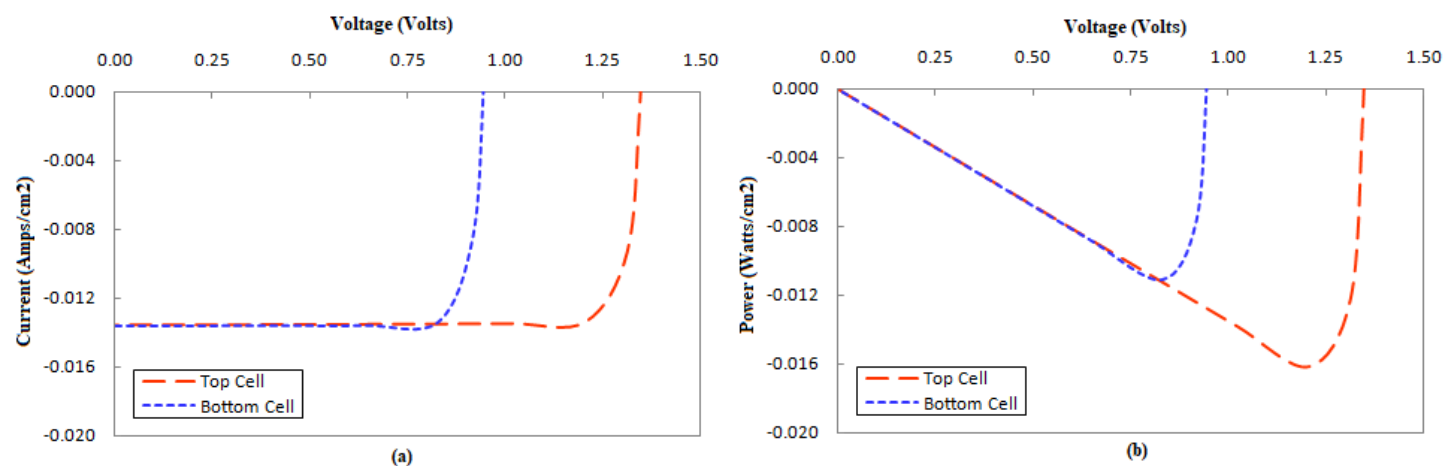

Fig.2. (a) I-V Characteristics (b) P-V Characteristics $\left(25^{\circ} \mathrm{C}\right)$

Table 1. Summary of the results for the Optimized Cell at $25^{\circ} \mathrm{C}$

\begin{tabular}{lllll}
\hline Cell/ Characteristics & $\mathrm{V}_{\mathrm{OC}}($ Volts $)$ & $\mathrm{I}_{\mathrm{SC}}\left(\mathrm{Amps} / \mathrm{cm}^{2}\right)$ & $\mathrm{FF}$ & $\eta$ \\
\hline Top Cell & 1.3450 & 0.0136 & 0.8856 & 0.0162 \\
Bottom Cell & 0.9546 & 0.0136 & 0.8627 & 0.0112 \\
Tandem Cell & 2.2996 & 0.0136 & 0.8761 & 0.0274 \\
\hline
\end{tabular}

\subsection{Effect of Temperature}

After the optimization of the solar cell, the effect of temperature on the top and the bottom cells were independently analyzed. The operating temperature was varied from $25^{\circ} \mathrm{C}$ to $100^{\circ} \mathrm{C}$ with a device area of $1 \mathrm{~cm}^{2}$. The simulations were performed under AM1.5G one sun illumination. The temperature dependence of the material parameters for GaInP and GaAs were taken into consideration before the simulations were performed $[13,14]$. The objective was to identify the dependence of the performance of the tandem cell for each of the electrical parameters already described.

The temperature dependence of bandgap in semiconductors can be described by [15]:

$$
E_{g}(T)=E_{g}(0)-\frac{\alpha T^{2}}{(T+\beta)}
$$

Where

$E_{g}(T)$ is the bandgap at a particular temperature

$E_{g}(0)$ is the bandgap at $0 \mathrm{~K}$

$\alpha$ and $\beta$ are constants for a particular semiconductor.

The temperature dependence of $V_{O C}$ can be calculated from equation (2) as:

$$
\frac{d V_{O C}}{d T}=\frac{V_{O C}}{T}+\frac{K T}{q}\left(\frac{d J_{S C}}{J_{S C} d T}-\frac{d J_{0}}{J_{0} d T}\right)
$$


An expression for the $F F$ without considering the resistive losses is given as [11]:

$$
F F=\frac{v_{O C}-\ln \left(v_{o c}+0.72\right)}{v_{o c}+1}
$$

where $v_{o c}$ is the normalized value of $V_{O C}$ with respect to the thermal voltage.

The variation of the $F F$ with temperature is governed by the equation (8) which can be derived from equation (7):

$$
\left.\frac{d F F}{d T}=\left(\frac{\frac{d V_{O C}}{d T}-\frac{V_{O C}}{T}}{V_{O C}+\frac{K T}{q}}\right)\left(\frac{\left(\frac{V_{O C}}{K T}-0.28\right.}{q}\right)-F F\right)
$$

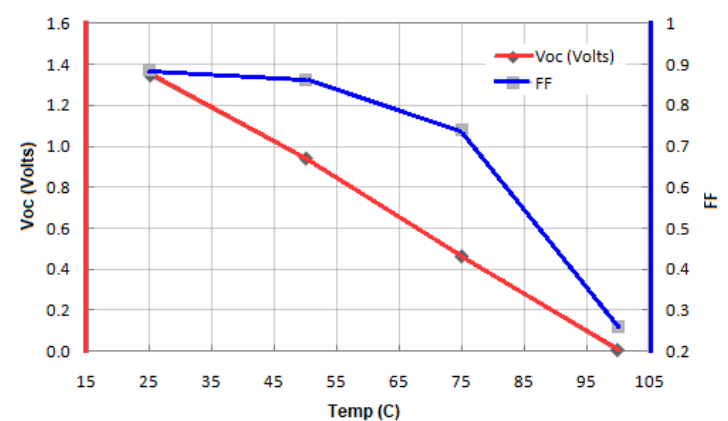

(a)

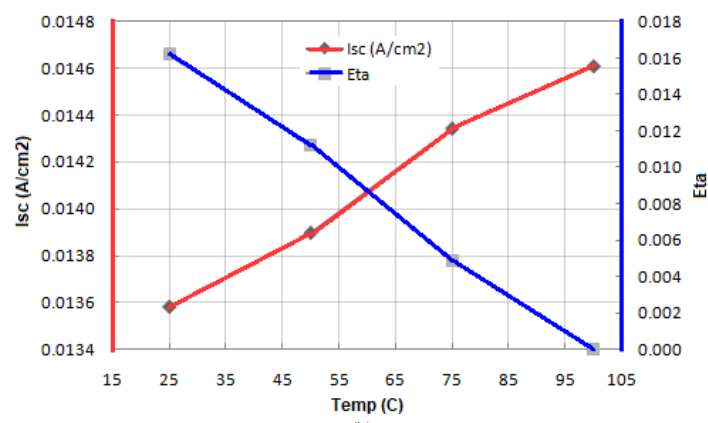

Fig.3. (a) VOC and FF (b) ISC and $\eta$ fort Different Temperatures (Top Cell)

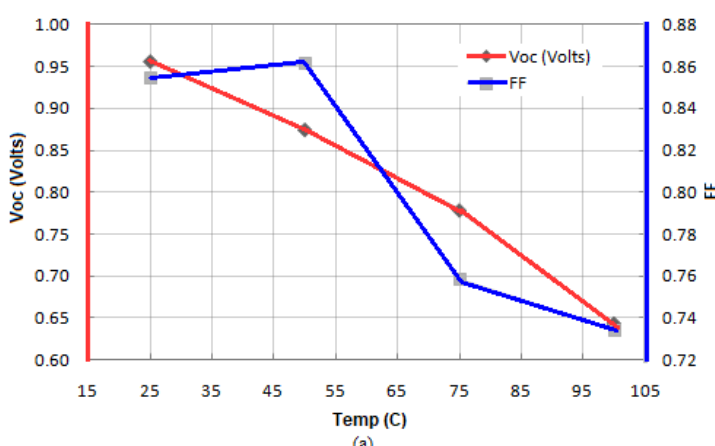

(a)

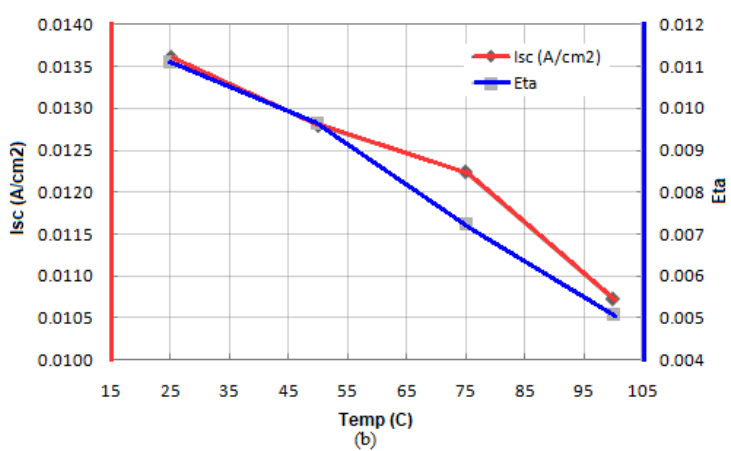

(b)

Fig.4. (a) VOC and FF (b) $\mathrm{I}_{\mathrm{SC}}$ and $\eta$ fort Different Temperatures (Bottom Cell) 
The Fig.3(a) and 4(a) indicates that the $\mathrm{V}_{\mathrm{OC}}$ decreases almost linearly for the top and the bottom cells. This decrease in $\mathrm{V}_{\mathrm{OC}}$ is because of the increase in the dark current density in the cells and is governed by the term $\mathrm{J}_{0}$ in the equation (7). The increase in the value of the dark current is primarily due to the temperature dependence of the intrinsic carrier concentration $\left(\mathrm{n}_{\mathrm{i}}\right)$ in the cell as evident from the equation (3). The $\mathrm{V}_{\text {OC }}$ decreases by 17.3 and $4.27 \mathrm{mV} /{ }^{\circ} \mathrm{C}$ rise in temperature for the top and the bottom cells respectively. Also the FF in general decreases for both the top and the bottom cell with increasing temperature because of the decrease in $\mathrm{V}_{\mathrm{OC}}$. However, there is an increase in the FF in the bottom cell from 25 to $50^{\circ} \mathrm{C}$. This variation in the FF can be attributed to its independence on the $\mathrm{I}_{\mathrm{SC}}$ for the case of the top cell and to its dependence on $\mathrm{I}_{0}$ for the bottom cell $\left(25^{\circ} \mathrm{C}-50{ }^{\circ} \mathrm{C}\right)$. The anomaly in the nature of the $\mathrm{FF}$ curve (increasing) in the temperature range of $25^{\circ} \mathrm{C}$ $50^{\circ} \mathrm{C}$ can be described in terms of its dependence on the reverse saturation current $\left(\mathrm{J}_{0}\right)$. This may be attributed to the fact that with the increase in temperature the intrinsic carrier concentration $\left(n_{i}\right)$ decreases because of increased recombination of the excess charge carriers. This results in a decreased value of $\mathrm{J}_{0}$ and increase in the FF. At temperatures over $50^{\circ} \mathrm{C}$, the generation rate exceeds the recombination rate resulting in the expected decrease in the $\mathrm{FF}$ curve. The $\mathrm{FF}$ decreases by $0.83 \%$ and $0.16 \% /{ }^{\circ} \mathrm{C}$ rise in temperature for the top and the bottom cell respectively.

The $\mathrm{I}_{\mathrm{SC}}$ increases for the bottom cell with an increase in the temperature, however for the bottom cell the $\mathrm{I}_{\mathrm{SC}}$ decreases with the increase in temperature as apparent from the Fig.3(b) and 4(b) respectively. The reason for the increase in $\mathrm{I}_{\mathrm{SC}}$ for the top cell can be ascribed to the increase in the intrinsic carrier concentration at higher temperatures. In contrast for the bottom cell, the $\mathrm{I}_{\mathrm{SC}}$ decreases with the increase in temperature because of the higher doping concentration present in the base layer resulting in increased recombination of the excess charge carriers and lower collection probability at the terminals. For the top cell and the bottom cell the $\mathrm{I}_{\mathrm{SC}}$ increases and decreases by 0.013 and $0.038 \mathrm{~mA} /{ }^{\circ} \mathrm{C}$ rise in temperature respectively. It can also be observed that the $\eta$ of the top and the bottom cell decreases with the increase in temperature. From equation (5) it can be observed that the efficiency depends on all the other electrical parameters in a solar cell. Therefore since the FF initially increases for the bottom cell and no similar trend is observed in $\eta$, it can safely be concluded that the effect of the FF on the efficiency is insignificant. The efficiency decreases by $0.213 \%$ and $0.08 \% /{ }^{\circ} \mathrm{C}$ rise in temperature for the top and the bottom cell respectively. These results are summarised in Table 2.

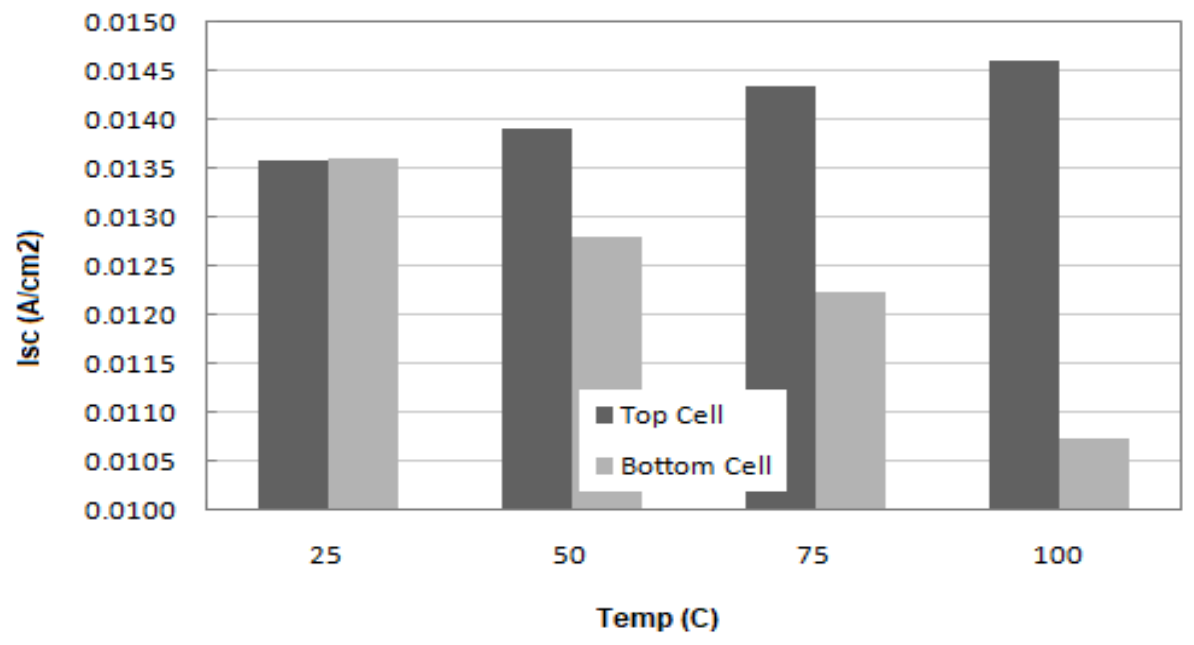

Fig.5. Difference in $\mathrm{I}_{\mathrm{SC}}$ of the top and the Bottom Cell at Different Temperatures

The Fig.5 emphasizes the results obtained after simulation suggesting that the short circuit current for top cell rises and for the bottom cell reduces with the increase in temperature with the difference getting 
progressively higher. It is also evident from the result presented in the Fig.5 that the current mismatch between the top and the bottom cell is greater at a higher temperature. It can also be noted that the variation in the current for the top cell is smaller compared to the variation in the current for the bottom cell. Therefore for the current match condition to be satisfied the tandem cell $\mathrm{I}_{\mathrm{SC}}$ is strongly dependent on the $\mathrm{I}_{\mathrm{SC}}$ value in case of the top cell.
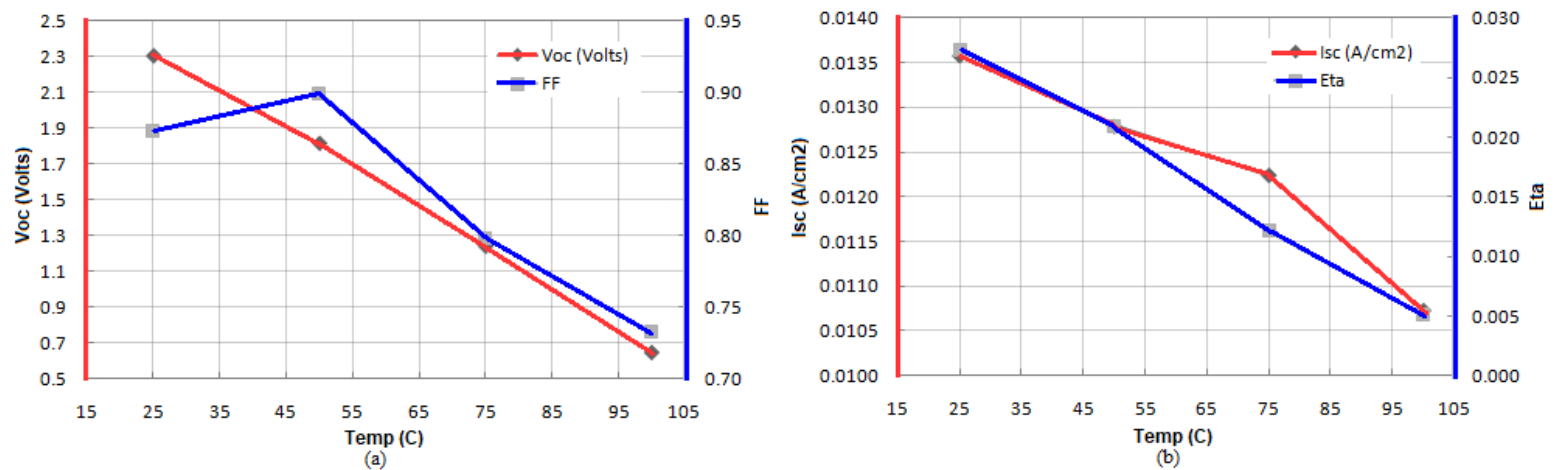

Fig.6. (a) VOC and FF (b) $\mathrm{I}_{\mathrm{SC}}$ and $\eta$ fort different temperatures (Tandem Cell)

For the tandem solar cell, the $\mathrm{V}_{\mathrm{OC}}$ is the sum of the open circuit voltages for the top and the bottom cells. Because the current equality criterion is to be fulfilled, the $\mathrm{I}_{\mathrm{SC}}$ is the short circuit current for the top or the bottom cell depending on whose value is lower. The efficiency of the tandem cell is simply the sum of the $\eta$ for the top and the bottom cells. The results obtained after simulation of the tandem solar cell is represented graphically in the Fig.6 (a) and (b).

Table 2. Variation of the Different Parameters with Respect to Temperature

\begin{tabular}{lllll}
\hline $\begin{array}{l}\text { Parameter variation } /{ }^{\circ} \mathrm{C} \\
\text { rise in temperature }\end{array}$ & $\Delta \mathrm{V}_{\mathrm{oC}} / \Delta \mathrm{T}\left(\mathrm{mV} /{ }^{\circ} \mathrm{C}\right)$ & $\Delta \mathrm{I} \mathrm{sc} / \Delta \mathrm{T}\left(\mathrm{mA} /{ }^{\circ} \mathrm{C}\right)$ & $\mathrm{FF}(\%)$ & $\eta(\%)$ \\
\hline Top cell & -17.3 & +0.013 & -0.83 & -0.213 \\
Bottom cell & -4.27 & -0.038 & -0.16 & -0.08 \\
Tandem cell & -22.6 & -0.027 & -0.187 & -0.293 \\
\hline
\end{tabular}

Table 3. Performance of GaInP/GaAs tandem cell

\begin{tabular}{lllll}
\hline Parameter & $\mathrm{V}_{\mathrm{OC}}($ Volts $)$ & $\mathrm{I}_{\mathrm{SC}}\left(\mathrm{mA} / \mathrm{cm}^{2}\right)$ & $\mathrm{FF}(\%)$ & $\eta(\%)$ \\
\hline $25^{\circ} \mathrm{C}$ & 2.3 & 13.6 & 87.3 & 27.3 \\
$100^{\circ} \mathrm{C}$ & 0.6 & 10.7 & 73.3 & 5.1 \\
Variation & $-73.9 \%$ & $-21.32 \%$ & $-16.03 \%$ & $-81.31 \%$ \\
\hline
\end{tabular}

Table 3 indicates the variation in the parameters of the proposed GaInP/GaAs based tandem solar cell. It suggests that for the proposed structure the percentage variation in the open circuit voltage and the efficiency of the solar cell is significantly greater than the variation in the short-circuit current and the fill factor. 


\section{Conclusion}

In this paper, investigations have been performed on a $\mathrm{GaInP} / \mathrm{GaAs}$ based stacked series connected tandem solar cell. The effect of temperature $\left(25^{\circ} \mathrm{C}-100^{\circ} \mathrm{C}\right)$ on each of the two cells has been studied independently to determine the performance of the resulting multijunction tandem solar cell. Studies have revealed that for the tandem cell the variation in the $\mathrm{I}_{\mathrm{SC}}$ is firmly dependent on the variation in $\mathrm{I}_{\mathrm{SC}}$ for the bottom cell. However, the performance of the tandem cell is majorly dependent on the performance of the top cell at higher temperatures. The increase in temperature results in a decrease in $\mathrm{V}_{\mathrm{OC}}, \mathrm{FF}$, and $\eta$ of the solar cell. For the proposed structure the $\mathrm{I}_{\mathrm{SC}}$ of the top cell and the bottom cell increase and decrease with temperature respectively. Because of the series connection, the efficiency of the tandem solar cell is limited by the solar cell that registers the lower current.

\section{References}

[1] Sleiman, Adam, and Mahieddine Emziane. "P/N/P Double-Junction GaAs/Ge Solar Cell Devices for PV and CPV." In Sustainability in Energy and Buildings, pp. 629-636. Springer Berlin Heidelberg, 2012.

[2] Emziane, M., and A. Sleiman. "Multi-junction solar cell designs." In 2011 IEEE GCC Conference and Exhibition (GCC).

[3] Yamaguchi M. Multi-junction solar cells and novel structures for solar cell applications. Physica E, 2002, 14(1): 84.

[4] King R R, Law D C, Edmondson $\mathrm{K} \mathrm{M}$, et al. 40\% efficient metamorphic $\mathrm{GaInP} / \mathrm{GaInAs} / \mathrm{Ge}$ multijunction solar cells. Appl Phys Lett, 2007, 90: 183516.

[5] M. Bosi, C. Pelosi, "The Potential of III-V Semiconductors as Terrestrial Photovoltaic Devices", Prog. Photovolt: Res. Appl, vol. 15, pp. 51-68, 2007.

[6] M. Yamaguchi, T. Takamoto, K. Araki, and N. Ekins-Daukes, "Multi-junction III-V solar cells: current status and future potentials," Sol. Energy, vol. 79, pp. 78-85, 2005.

[7] F. Dimroth and S. Kurtz, "High-efficiency multijunction solar cells," MRS Bull., vol. 32, pp. 230-235, 2007.

[8] S. Nann, K. Emery, Spectral effects on PV-device rating, Sol. Energy Mater. Sol. Cells. 27 (1992) 189216. doi:10.1016/0927-0248(92)90083-2.

[9] S. Yoon, V. Garboushian, Reduced temperature dependence of high-concentration photovoltaic solar cell open-circuit voltage (Voc) at high concentration levels, Proc. 1994 IEEE 1st World Conf. Photovolt. Energy Convers. - WCPEC (A Jt. Conf. PVSC, PVSEC PSEC). 90505 (1994) 1500- 1504.

[10] J.J. Wysocki, P. Rappaport, Effect of temperature on photovoltaic solar energy conversion, J. Appl. Phys. 31 (1960) 571-578.

[11] M.A. Green, Solar cells: operating principles, technology, and system applications, Prentice-Hall, Englewood Cliffs, NJ, 1982.

[12] Geoffrey A. Landis, Danielle Merritt, Ryne P. Raffaelle, and David Scheiman, "High temperature solar cell development," 18th Space Photovoltaic Research and Technology Conference, 2005, pp. 108-115.

[13] A. Mc. Evoy, T. Markvart, L. Castaner, Practical Handbook of Photovoltaics Fundamentals and Applications, Second Edition, Elsevier Ltd, 2012.

[14] P. Basmaji, M. Guittard, A. Rudra, J.F. Carlin, P. Gibart, "GaAs tunnel junction grown by metalorganic vapor-phase epitaxy for multigap cascade Solar cells", Journal of Applied Physics, vol. 62, pp. 21032106, 1987.

[15] Y.P. Varshni, Temperature dependence of the energy gap in semiconductors, Physica 34 (1967) 149154. 


\section{Authors' Profiles}

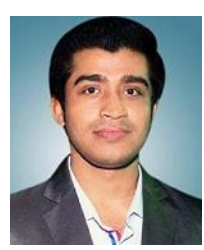

Debashish Pal received his Bachelor of Engineering degree from Berhampur University, Odisha and his M. Tech degree from WBUT, West Bengal. He served as an Assistant Professor in the Department of Electronics and Communication Engineering, Surendra Institute of Engineering and Management, Siliguri.

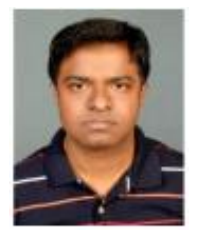

Rabi Adhikary, BSc. (Electronics), B. Tech and M. Tech in Electronics \& Communication Engineering served as an Assistant Engineer in Electronics \& Communication Dept, Surendra Institute of Engineering \& Management, West Bengal, India and is presently working as a lecturer in the Electronics and Telecommunication Dept, Pailan Technical Campus, Kolkata.

How to cite this paper: Debashish Pal, Rabi Adhikary,"Studies on the Performance of a GaInP/GaAs Tandem Solar Cell at Elevated Temperatures", International Journal of Engineering and Manufacturing(IJEM), Vol.9, No.1, pp.38-46, 2019.DOI: 10.5815/ijem.2019.01.04 